\title{
Changing Patterns of Health and Disease Among the Aleuts
}

\author{
Anne Keenleyside
}

\begin{abstract}
Compared to other regions of North America, there have been relatively few paleopathological studies of arctic populations to date, particularly those aimed at elucidating patterns of health and disease prior to contact, and assessing temporal changes in disease patterns. In the present study, four Aleut skeletal samples representing one pre-contact population from Umnak Island in the eastern Aleutian Islands $(\mathrm{N}=65)$, and three late pre-contact/early contact period populations from Umnak, Kagamil, and Shiprock Islands $(\mathrm{N}=227)$, were examined macroscopically for indicators of health status. The analysis revealed some evidence of declining health in the late pre-contact/early contact period. Statistical comparisons of the earlier and later samples indicated a significantly higher frequency of cribra orbitalia and cranial infection in the later sample compared to the earlier one. Archaeological, epidemiological, and historical data point to several possible explanations for these findings, including the introduction of new pathogens by Europeans.
\end{abstract}

\section{Introduction}

In the last decade, a large number of skeletal stud-

E ies of health and disease in pre- and post-contact populations from North and South America (e.g., B Baker and Kealhofer 1996; Larsen 1994, 2001; Larsen and Milner 1994; Verano and Ubelaker 1992) have been published. These studies have demonstrated the presence of a substantial pathogen load in some pre-contact populations, and have revealed evidence of declining health following European contact (Aufderheide 1992; Ubelaker and Verano 1992). With respect to arctic populations, studies of mummies from the Aleutian Islands (Zimmerman et al. 1971, 1981), frozen cadavers from Point Barrow (Zimmerman and Aufderheide 1984) and St. Lawrence Island (Zimmerman and Smith 1975), and skeletal remains (eg. Keenleyside 1998; Lobdell 1980; Merbs 1983; Salter 1984; Stewart 1932, 1979; Way 1978) have yielded information on Eskimo and Aleut health prior to contact. However, there have been few investigations aimed at examining temporal changes in disease patterns and the biological impact of European contact on these populations. One exception is Meer's (1985) analysis of two early contact period skeletal samples from Chirikof Island in southern Alaska, which revealed little evidence of physiological stress despite contact with Russians. Consequently, much of what is known about the health of arctic populations following contact has been derived from other sources of information, such as historical accounts, traditional healing practices, and inferences from modern scientific knowledge (Fortuine 1989).

This paper presents the results of an analysis of pre-contact and late pre-contact/early contact period Aleut skeletal remains from the eastern Aleutian Islands. Its aims are to 1) examine temporal 
changes in patterns of health and disease among the Aleuts, and 2) determine whether some of these changes might be related to European contact.

\section{Background}

The Aleuts occupy a volcanic island chain characterized by rocky coastlines and moderate temperatures. Archaeological evidence indicates that their ancestors exploited a wide variety of marine resources, including seals, sea otters, sea lions, whales, and numerous species of fish, shellfish, and birds (Laughlin and Aigner 1975; Lippold 1966; McCartney 1984). Aleut settlements were located primarily on the coast, and consisted of large, permanent settlements and temporary camps (McCartney 1984). At the time of European contact (ca. mid-eighteenth century), dwellings were large, semisubterranean structures constructed of driftwood and whalebones, covered with grass, sod, and skins, and heated with stone lamps (McCartney 1984). The Aleuts' traditional garment was a parka made of sea mammal or bird skins (Lantis 1984). Large, open boats and kayaks were used for hunting and traveling. The Aleuts traded amongst themselves, and reportedly engaged in frequent conflict with one another and with neighboring Eskimos (Lantis 1984; Veniaminov [1840] 1984).

The first contact between Aleuts and Russians occurred in 1741, when Vitus Bering and Alexei Chirikov landed their ships in the Aleutian Islands. Although their expedition did not achieve its original goal of establishing Russian sovereignty in north western North America (VanStone 1984:149), the valuable cargo of sea otter pelts obtained during the voyage stimulated the organization of commercial fur-hunting expeditions to the Aleutians in the years that followed (Black 1980:92). The first Russian fur hunters landed in the islands in 1745 to hunt sea otters and other fur-bearing animals (Black 1984:72). Initially the Russians engaged in the hunt themselves (Liapunova 1987:114), but they became increasingly reliant on the Aleuts to provide them with pelts, either through trade or coercion (Bancroft 1959:121; Liapunova 1987:115). To ensure the safety of their own hunting parties, the Russians took Aleut hostages, by force or persuasion (Masterson and Brower 1948:60).

In the early years of the fur trade, the Russian government made little effort to protect the welfare of the Aleuts (Hulley 1953:57). Consequently, relations between the Russians and Aleuts were not always amicable, and on a num- ber of occasions, hostile encounters resulted in injury and death to both groups (Bancroft 1959:103, 105 122; Berkh [1823] 1974:5, 19; Black 1984:82, 85 87; Coxe 1780:34; Jochelson 1968:3). As Black (1980:93) has noted, the outcome of these encounters, which were local and sporadic, depended to a great extent on the character of the individuals involved, and some early traders did succeed in establishing good relations with the Aleuts (Berkh [1823] 1974:17, 18, 30; Black 1984:75; Makarova 1975:52).

Moving eastward along the island chain as sea otters became increasingly scarce and the western islands became overcrowded with hunting parties (Black 1984:76), the Russians reached Umnak Island in 1759 and the Alaskan mainland in 1762 (Black 1980:93). By this time, the number of vessels visiting the chain annually for the purpose of hunting had increased from one to as many as ten vessels (Black 1984:75). As the fur trade increased, so too did the violence against the Aleuts (Black 1980:94), many of whom opposed Russian demands to assist in the fur hunts. Among the most notable abuses committed during this time period were those of the merchant Bechevin and his crew, who were responsible for a number of native deaths (Bancroft 1959:124, 125; Berkh [1823] 1974:25). It has been argued that the behavior of Bechevin and his crew was likely to have precipitated the organized uprising of the eastern Aleuts during the winter of 1763/1764 (Black 1984:86). In surprise raids against several Russian fur-hunting parties, the Aleuts destroyed four vessels wintering on Umnak, Unimak, and Unalaska Islands, and reportedly killed an estimated 200 Russian crewmen (Black 1980:94). In retaliation for the death of their comrades, the Russian survivors of the uprising are said to have destroyed numerous villages from Umnak Island to Akutan Pass (Hulley 1953:60), killing 200 to 300 Aleut warriors (Bancroft 1959:151; Berkh [1823] 1974:41; Veniaminov [1840] 1984:251).

In 1768, the Russian government undertook an expedition, under the command of CaptainLieutenant Petr Krenitsyn and Lieutenant Mikhail Levashov, to explore and map the islands, to secure the territory for the Russian Empire, to bring the Aleuts under Russian citizenship, and to regulate the collection of tribute (Glushankov 1973:205). The expedition eventually succeeded in charting the eastern end of the island chain, despite several skirmishes with the Aleuts and the loss of over 30 crewmen from scurvy. Levashov, who took an interest in the customs of the local 
inhabitants, left valuable ethnographic observations and sketches of the Unalaska Aleuts (Glushankov 1973; Masterson and Brower 1948:57-61). He also enforced the government policy of "fair and equitable treatment" of the Aleuts, even though he reportedly disliked them personally (Black 1980:95).

From 1778 to 1779, Captain James Cook, on an expedition in search of a northern passage to the Atlantic, passed through the Aleutians, stopping briefly at Unalaska Island. By this time, most of the natives had seen subjugated by the Russians (Bancroft 1959:169), and the Aleut population, estimated to have numbered 12,000 to 15,000 prior to Russian contact (Veniaminov 1984:246), had been reduced by at least one-third (Laughlin 1980:129). By 1780 most of the Aleutian Islands had been discovered and mapped (Fedorova 1973:105) and the ङ્ fur trade had reached its peak (Makarova 1975:77). Although the number of vessels making annual Dvoyages to the Aleutians still remained relatively ôsmall, overcrowding of the Andreanof Islands by fur hunters resulted in increased conflicts between ธิ่ rival fur-trading companies as they attempted to lay کclaims to specific hunting grounds (Black 1984:92). As competition for greater catches and profits inCreased, so too did the Russians' reliance on Aleut ohunters (Black 1981:118, 1984:81). Consequently, $\vec{s}$ the Russian practice of forcing the Aleuts to hunt ङ્ofor them became increasingly common.

을 Following the discovery of the Pribilof Islands Iin 1786, many Aleuts were transported from the central Aleutians to the Pribilofs to hunt, some Dु never returning home (Black 1984:96). By this time, or reports of the mistreatment of Aleuts by the Russians had reached the Imperial Government, and an expedition under the command of Captain Joseph Billings was dispatched to investigate allegations of Aleut brutalities at the hands of the Russian fur hunters. When the expedition arrived in the islands in 1790, only one third of the original Aleut population remained (Sarychev 1807:72). Wintering at Unalaska in 1791/1792, the crew confirmed earlier reports of Aleut abuses and were, themselves, witnesses to these abuses (Merck [1788-1792] 1980:80). Although the expedition succeeded in putting an end to the murder of natives (Veniaminov [1840] 1984:256), the practice of forced labor continued (Milan 1974:19), particularly in the more densely populated eastern Aleutians where native resistance was stronger (Black 1984:81).

The last private trading vessel was dispatched to the island chain in 1792 (Makarova 1975:119), and in 1799, the consolidation of several fur-trading companies resulted in the forma- tion of the Russian-American Company. Although the Company's first charter contained no guidelines regarding the treatment of Aleuts (Okun 1951:197), its second charter, issued in 1821, outlined its policy regarding this matter in a section entitled "On the Islanders" (Liapunova 1987:139). Unfortunately, the lack of government officials in the colony prevented the enforcement of the charter, and the exploitation of the Aleuts continued (Okun 1951:195). In the first two decades of the Company's operation, hundreds of Aleuts were relocated and forced to travel increasingly further distances to hunt the rapidly diminishing sea otter population. Many of these individuals subsequently drowned (Veniaminov [1840] 1984:256).

Compounding the loss of population due to forced resettlement were episodes of famine that periodically struck the Aleut population (Coxe 1780:259; Masterson and Brower 1948:58), and the continued onslaught of epidemic diseases that were introduced to the Aleuts by the Russians. These included influenza, smallpox, and measles (Bancroft 1959; Black 1984; Tikhmenev 1978; Veniaminov [1840] 1984). By 1867, when the United States government purchased Alaska, the Aleut population numbered only 2,500 (Hulley 1953:16).

\section{Description of the Skeletal Samples}

A total of four skeletal samples representing one pre-contact Aleut population $(\mathrm{N}=65)$ from Umnak Island in the eastern Aleutian Islands and three late pre-contact/early contact period populations $(\mathrm{N}=227)$ from Umnak, Kagamil, and Shiprock Islands (Fig. 1) were selected for analysis (Table 1). For 141 of these individuals, only the cranium and/or mandible were present, while the remaining 151 individuals had complete or nearly complete skeletons. The collections are currently housed in the Department of Anthropology, National Museum of Natural History, Smithsonian Institution.

The pre-contact sample from Umnak Island was excavated by Hrdlička in 1938 from the Chaluka site, a 4,000-year old village site located within the present-day village of Nikolski (Fig. 1). All of the skeletons are dolichocephalic "PaleoAleuts," believed to have evolved into the brachycephalic "Neo-Aleuts" of the historic period (Laughlin 1963). The Paleo-Aleut skeletons were recovered from the lower, middle, and upper levels of the site and date from ca. 1000 B.C. to 1500 A.D. (Laughlin 1992:6). Despite the temporal depth of these remains, archaeological evidence from Chaluka indicates homogeneity in both 


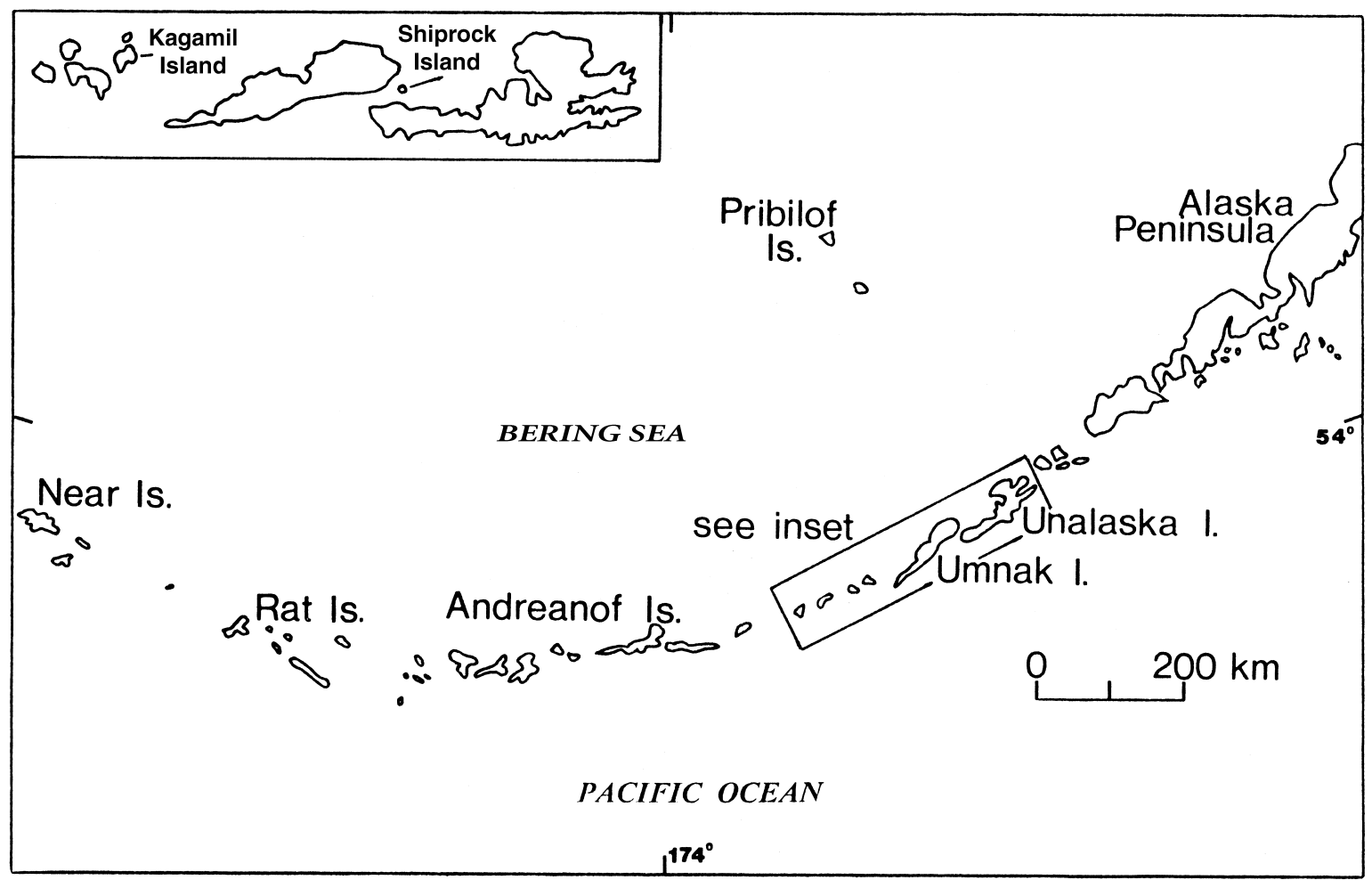

Figure 1. Map of the Aleutian Islands.

Table 1. Skeletal samples used in the study.

\begin{tabular}{lcc}
\hline Sample & Minimum \# of Individuals & Temporal Position \\
\hline $\begin{array}{l}\text { Pre-Contact Period } \\
\text { Umnak Island I }\end{array}$ & 65 & \\
Late Pre-Contact/Early & & 1000 B.C.-A.D. 1500* \\
Contact Period & & \\
Umnak Island II & 6 & \\
Shiprock Island & 62 & 18th century** \\
Kagamil Island & 159 & 14th-18th century*** \\
Total & 227 & A.D. 1400-1780**** \\
Overall Total & $\mathbf{2 9 2}$ & \\
\hline
\end{tabular}

*Hrdlička, 1945; Laughlin, 1963, 1992

**Hrdlička, 1945; Turner et al., 1974

***Hrdlička, 1941, 1945; Turner, 1991

****Hrdlička, 1941, 1945; Heathcote, 1986; Laughlin, 1980, 1992; Utermohle, 1984

material culture and diet throughout this period (Laughlin 1963).

The late pre-contact/early contact period samples were collected by Hrdlička from 1936 to 1938. The Umnak Island sample consists of the remains of six individuals excavated from the uppermost layers of the Chaluka site. Classified by
Hrdlička as "Aleut" (i.e., Neo-Aleut) on the basis of their craniometrics (Hrdlička 1945), the remains were found in both flexed and extended positions, the latter possibly reflecting European influences (Turner et al. 1974:140). Hrdlička (1945:371) noted evidence of possible venereal syphilis in one of these skeletons, and commented that none of the 
pre-contact burials from the site showed any evidence of the disease.

The Shiprock Island sample consists of the remains of 62 individuals recovered from two rock shelters on Shiprock Island in Umnak Pass (Fig. 1). These shelters are believed to have been used primarily by eastern Umnak Aleuts (Turner 1991:16). In addition to the skeletal remains, Hrdlička recovered a variety of artifacts, including stone knives, lamps, scrapers, and white glass beads, indicating an early post-contact date for at least some of the remains (Hrdlička 1941b:119, 1945: 335). While the total time span represented by this sample is unknown, the remains likely date from the fourteenth to the eighteenth century (Turner 1991).

The Kagamil sample consists of the remains of 159 individuals removed from two caves located on \&ेthe southwest coast of Kagamil Island in the eastern Aleutians (Fig. 1). First entered by Europeans in 1874, when 12 mummies and several skulls were örecovered (Hrdlička 1941a:9), the caves were later . explored by Hrdlička who, in 1936, retrieved more ¿ than 50 mummies, mostly children, as well as approximately 30 skulls and various infracranial reThains from the "warm" cave (Hrdlička 1941a:16, 1945:242). A subsequent survey of the "cold” cave ¿yielded 24 sacks of bones of much poorer preservation (Hrdlička 1941a:18, 1945:244-245). In addition हo to the human remains, a wealth of cultural material ๖ेwas collected from the caves, including decorated छี matting, feather garments, cords, kayak frames, parts of war shields, ivory labrets, stone lamps, and Ð s slate knives (Hrdlička 1941a:18, 1945:242-243, 245). Dall (1875), Jochelson (1925), Veniaminov ([1840] 1984), and Laughlin (1980) provided detailed descriptions of the Kagamil burials.

The dating of the Kagamil material has been the subject of on-going debate. While radiocarbon dating of mask fragments recovered from the cold cave has yielded a date of ca. 900 to 1100 B.P. (Theodore Bank, personal communication 1979, cited in Black 1983:57), both Hrdlička (1941b:124) and Laughlin (1980:101) note that the remains are probably only a few hundred years old and that some of them date from the period of Russian contact, as indicated by the presence of canvas, glass beads, and probable cases of syphilis (Laughlin 1980:101). Relatively recent dates of A.D. 1700 to 1800 (Heathcote 1986:36) and A.D. 1400 to 1780 (Laughlin 1992:6) have been assigned to the sample. While the total time period represented by the Kagamil remains is unknown, the artifacts associated with the remains suggest that the majority span less than 600 years (Laughlin 1992:19).

\section{Methodology}

The sex of each individual was determined using standard morphological criteria of the cranium and pelvic bones (Bass 1987; Ubelaker 1989). Subadult age estimates were obtained using dental eruption, diaphyseal length, and degree of epiphyseal union (Ubelaker 1989), while adult age estimates were based on pubic symphysis morphology (Suchey and Katz 1986; Suchey et al. 1988), sternal rib end morphology (Iscan et al. 1984, 1985), and maxillary suture obliteration (Mann et al. 1991). For the purposes of the analysis, adults were assigned to one of four age categories: 18-20 years, 21-35 years, 36-50 years, and 50+ years. The sex and age distributions of the samples are illustrated in Table 2.

The health and nutritional status of past populations and temporal changes in health can be assessed using a variety of skeletal and dental indicators. Recognizing that health is "a composite

Table 2. Age and sex distributions of the skeletal samples.

Pre-Contact Period

Late Pre-Contact/Early Contact Period

\begin{tabular}{|c|c|c|c|c|c|c|c|c|}
\hline Age & Males & Females & Unknown & Total & Males & Females & Unknown & Total \\
\hline $\begin{array}{l}\text { Subadult } \\
(<18 \mathrm{yrs})\end{array}$ & 1 & 0 & 4 & 5 & 5 & 9 & 64 & 78 \\
\hline $\begin{array}{l}\text { Young Adult } \\
\text { (18-35 yrs) }\end{array}$ & 4 & 4 & 0 & 8 & 29 & 27 & 0 & 56 \\
\hline $\begin{array}{l}\text { Middle Adult } \\
(36-50 \mathrm{yrs})\end{array}$ & 8 & 4 & 0 & 12 & 34 & 10 & 0 & 44 \\
\hline $\begin{array}{l}\text { Older Adult } \\
(50+\mathrm{yrs})\end{array}$ & 17 & 23 & 0 & 40 & 19 & 30 & 0 & 49 \\
\hline Total & 30 & 31 & 4 & 65 & 87 & 76 & 64 & 227 \\
\hline
\end{tabular}


of nutrition, disease, and other aspects of life history" (Larsen 1997:8), physical anthropologists commonly employ multiple indicators in order to obtain a more complete assessment of health and disease in the past. Conditions typically recorded in skeletal remains include cribra orbitalia and porotic hyperostosis, trauma, infections, enamel hypoplasia, dental caries, dental abscesses, antemortem tooth loss, periodontal disease, and dental attrition. Cribra orbitalia and porotic hyperostosis, conditions characterized by porosity and thickening of the cranial vault and superior orbital plates, have been attributed largely to iron deficiency anemia resulting from a low dietary intake of iron, poor intestinal absorption of iron, and/or excess loss of iron due to infectious diseases (El-Najjar et al. 1976; Goodman et al. 1984; Ortner and Putschar 1985; Steinbock 1976). In addition, these conditions have been linked to other health problems, including scurvy, rickets, tumors, and inflammatory processes of the cranial vault and scalp (Schultz 2001:131). They have also been viewed as an adaptive response to a high pathogen load in which the body withholds iron as a form of defence against invading pathogens that require iron for growth and development (StuartMacadam 1992). Given the introduction of new infectious diseases to the Aleuts following contact, one might expect to see an increase in cribra orbitalia and porotic hyperostosis in the postcontact skeletal samples.

Trauma to the skeleton may be classified into four categories: 1) fractures, 2) dislocations and displacements, 3) disruptions in nerve or blood supply, and 4) artificial deformation (Ortner and Putschar 1985:55). Fractures, the most common type of traumatic injury observed in archaeological populations (Goodman et al. 1984:34), can provide valuable insight into the activity patterns of past populations, as well as levels of interpersonal conflict within and between populations (Lovell 1997). They therefore have the potential to shed light on the nature of the relationship between the Aleuts and Russians. Historical records document numerous atrocities committed on the Aleuts by Russians (Veniaminov [1840] 1984). It is therefore hypothesized that the post-contact skeletal samples will exhibit a higher frequency of trauma than the pre-contact sample.

Infections in bone can be classified as either specific or non-specific. Since acute infectious diseases leave no evidence in bone, skeletal evidence represents chronic infections that may or may not have been the direct cause of death of an individual (Ortner and Putschar 1985:105). Non-specific infections are more common in archaeological remains and can be classified into two groups, periostitis, an inflammation of the periosteum resulting from localized trauma or infection (Ortner and Putschar 1985:132), and osteomyelitis, an inflammation of the marrow cavity caused by various bacteria (Steinbock 1976:60). Specific infections that can affect bone include tuberculosis and venereal syphilis. Previous studies of pre- and postcontact skeletal remains from North and South America have revealed evidence of increased rates of infection following contact (Verano and Ubelaker 1992). Therefore, one might expect to see an increased frequency of infection in the post-contact Aleut samples, particularly specific infections such as syphilis, which was known to have been introduced to the Aleuts following contact (Merck [1788-1792] 1980; Veniaminov [1840] 1984).

A study of dental pathology can provide important clues to the general level of health and nutritional status of a population (Waldram et al. 1995). In northern indigenous populations, antemortem tooth loss has been attributed to heavy attrition, trauma, and periodontal disease (Costa 1980; Merbs 1968). Enamel hypoplasia, a deficiency in enamel thickness resulting from nutritional stress, infectious diseases, and other forms of stress (Larsen 1997), has been used to investigate health changes associated with changes in subsistence practices and other cultural transitions. An increase in enamel hypoplasia over time in some populations has been linked to increased nutritional and disease stress resulting from the introduction of agriculture (Cohen and Armelagos 1984), and from European contact (Larsen and Milner 1994). Temporal changes in the incidence of dental caries have been linked to the introduction of refined sugars in modern-day Inuit populations (Mayhall 1970, 1975). It is hypothesized that the post-contact Aleut samples will exhibit a significantly higher frequency of both enamel hypoplasia and dental caries, reflecting the introduction of new pathogens and dietary changes following contact.

In the present study, all crania were examined macroscopically for evidence of cribra orbitalia and porotic hyperostosis. Cribra orbitalia was scored as present in an individual if at least one orbit was affected. Lesions were further characterized as unremodeled or remodeled based on the criteria of Mensforth et al. (1978). Porotic hyperostosis was scored as present if the cranium 
exhibited both pitting and thickening of bone. Crania exhibiting pitting without thickening of the vault were classified as having ectocranial porosis (Mann and Murphy 1990). Traumatic lesions were classified by type (i.e., fracture, dislocation, amputation), location in the skeleton, size and location on each bone, and stage of healing (healing/healed vs. unhealed). Complications resulting from trauma were also recorded. Elements exhibiting evidence of infection secondary to a traumatic injury were included under the category of trauma. Infectious lesions were classified by type (i.e., bone formation, bone loss, or both), location in the skeleton, size and location on each bone, and stage of healing (active vs. healing/healed). Following the recommendations of the Skeletal Database Committee (Rose et al. 1991), long bones that were less than two thirds ¿्रेcomplete were eliminated from the calculation of trauma and infection frequencies unless they exhibited evidence of these conditions (no cases). Due to ôlimited access to X-ray facilities, only a small number of specimens with infectious or traumatic le¿ิ่ sions were radiographed.

Enamel hypoplasia was classified according to the Developmental Defects of Enamel (DDE) Index (Federation Dentaire International 1982). Beocause of the variation in timing and susceptibility $\vec{\nabla}$ of defects between tooth types (Goodman and כ્0.Armelagos 1985), observations were recorded by ล̊individual tooth type. Hypoplastic defects were Eidentified by visual examination and were scored as present or absent for each of the six anterior o maxillary and mandibular teeth. All observed deof fects were further classified as either linear arrangements of pits, horizontal grooves, or both, and the total number of defects was recorded for each affected tooth. Those teeth that exhibited severe attrition resulting in the loss of more than one third of the tooth crown, heavy calculus deposits, severe caries, or trauma were excluded from the calculation of hypoplasia frequency. Dental caries, abscesses, antemortem tooth loss, and periodontal disease were recorded by individual and by tooth/tooth socket. Dental caries and abscesses were identified by visual examination and were classified by location and size, according to the criteria utilized by Patterson (1984). Teeth were recorded as having been lost antemortem if there was clear evidence of some remodeling of the tooth socket. Periodontal disease was assessed by the shape and appearance of the interdental septa, following the methodology employed by Costa (1982). The degree of dental attrition was recorded for each tooth using Smith's (1984) 8-stage scale.
To facilitate statistical analysis of the data, these stages were grouped into four larger categories following Beckett and Lovell (1994): no wear, slight wear (stages 1-3), moderate wear (stages 4-6), and severe wear (stages 7-8).

Following frequency calculations of each of the health indicators, statistical comparisons were made using the chi-squared test of independence, corrected for Yates continuity. Fisher's exact test was used when the number of cases was less than 20. Statistical analyses were performed using EpiInfo, Version 5. The analyses were done to determine whether any significant differences exist between the earlier and later samples with respect to each indicator. For the purposes of these comparisons, the three late pre-contact/early contact period samples were grouped into one larger sample. The rationale for combining these samples is as follows: 1) the samples are geographically close,

2) they represent eastern Aleuts, a group that is linguistically, morphologically, and culturally distinct from western Aleuts (Black 1984; Laughlin and Aigner 1975), and 3) they represent Neo-Aleuts who are believed to have evolved locally from earlier Paleo-Aleuts (Laughlin 1963, 1980; Turner et al. 1982). In addition, separate statistical comparisons were also made between the pre-contact sample and the Shiprock and Kagamil samples. The late pre-contact/early contact period sample from Umnak Island was too small to make any valid statistical comparisons with the pre-contact sample.

\section{Results}

The frequency of cribra orbitalia, porotic hyperostosis, trauma, and infection by individual is presented in Figure 2. There was no significant difference between the earlier and later samples in the frequency of porotic hyperostosis. In contrast, the later sample had a significantly higher frequency of cribra orbitalia than the earlier sample (51/221 compared to $2 / 54$ individuals, $x^{2}=9.26, p=.0023$ ), suggesting a possible increase in iron deficiency anemia due to dietary changes and/or an increase in infectious diseases. The significant difference between the two samples persisted when cribra orbitalia and porotic hyperostosis were combined (56/227 vs. $2 / 55$ individuals, $\left.x^{2}=10.74, p=.0010\right)$. Similar results were obtained when separate comparisons were made between the pre-contact sample and the Shiprock and Kagamil samples.

Of the 53 crania examined in the pre-contact sample, 8 (15.09\%) showed evidence of trauma consisting primarily of small, healed depression 


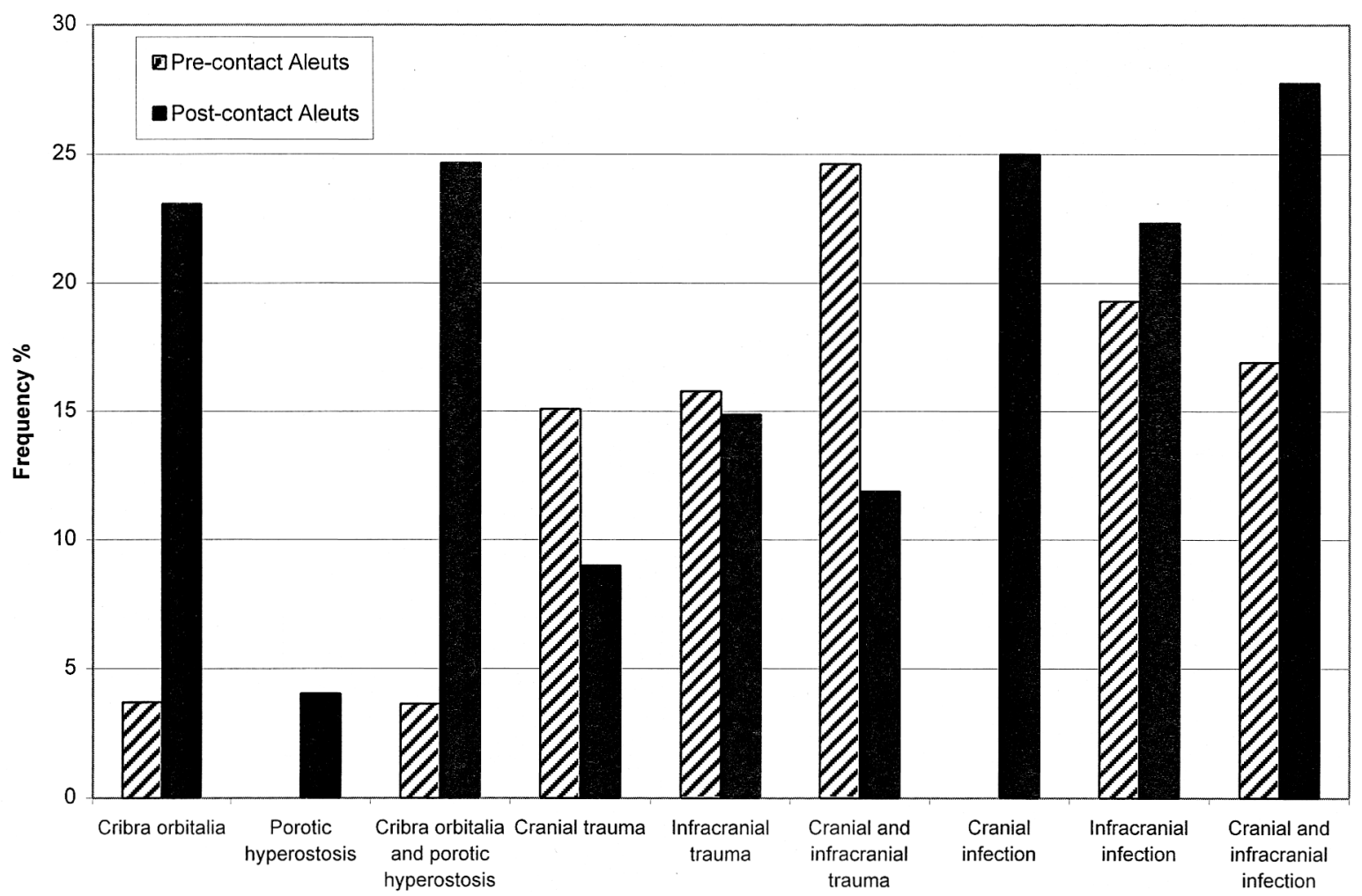

Figure 2. Frequency of cribra orbitalia, porotic hyperostosis, trauma, and infection by individual.

fractures of the frontal, parietal, and occipital bones. In contrast, 18 individuals (9\%) in the later sample showed evidence of cranial trauma. A statistical comparison of the earlier and later samples revealed no significant difference between the two. However, when the pre-contact sample was compared with only the Shiprock sample, the latter sample had a significantly lower frequency of cranial trauma than the earlier sample $(1 / 58 \mathrm{com}-$ pared to $8 / 53, \chi^{2}=4.97, p=.0132$ ). Possible explanations for this observation include changes in activity patterns and/or a decline in interpersonal violence.

Nine out of 57 individuals (15.79\%) in the pre-contact sample had partly or completely healed fractures of one or more of the ribs, radii, scapulae, humeri, femora, fibulae, pelvic bones, and hand and foot bones, while 14 out of 94 individuals $(14.89 \%)$ in the later sample had partly or completely healed fractures involving one or more of the ribs, radii, scapulae, clavicles, fibulae, pelvic bones, and foot bones. Consistent with historical accounts of numerous atrocities committed on the Aleuts by Russians was the discovery of a musket ball embedded in the pelvic bone of an adult male from Kagamil Island (Fig. 3). There was no statistically significant difference between the two samples with respect to infracranial trauma by individual or by element (all major long bones combined) (Table 3). However, when cranial and infracranial trauma were combined in order to assess the overall prevalence of trauma in the study samples, the earlier sample had a significantly higher frequency of trauma than the later sample (16/65 compared to 27/227 individuals, $\chi^{2}=5.54$, $\mathrm{p}=.0186)$. Similarly, when the pre-contact sample was compared to only the Shiprock sample, the former had a significantly higher frequency of trauma than the latter (16/65 compared to $1 / 62$ individuals, $\left.\chi^{2}=12.57, \mathrm{p}=.0004\right)$. Again, changes in activity patterns and/or the level of interpersonal violence may underlie these differences.

None of the 52 observable crania in the precontact sample displayed any evidence of cranial infection. In contrast, 51 out of 204 crania (25\%) in the later sample showed evidence of infection, a statistically significant difference $\left(\chi^{2}=14.70\right.$, $\mathrm{p}=.0001$ ). Affected elements included the frontal, parietal, occipital, nasal, zygomatic, maxillary and temporal bones, the sphenoid, and mandible. Of the 51 affected individuals, 19 (37.2\%) had active lesions at the time of their death. When separate 


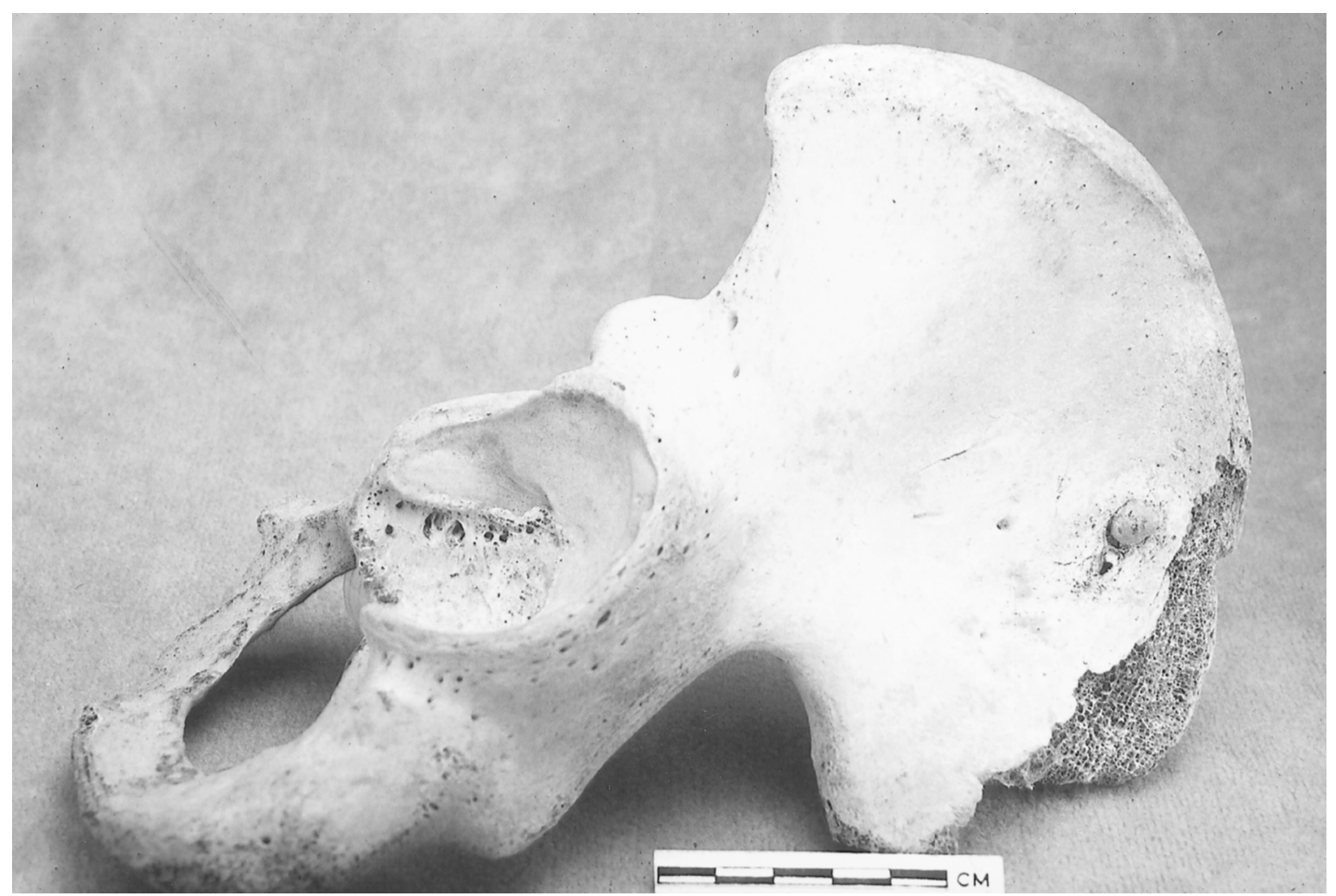

Figure 3. Musketball embedded in the left illium of an adult male from Kagamil Island.

क्ष

ठ̀comparisons were made between the Shiprock and Eagamil samples and the pre-contact sample, both of the later samples had significantly higher freक्ष quencies of cranial infection than the earlier samof ple $\left(\chi^{2}=24.15, \mathrm{p}<0.00001\right.$ and $\chi^{2}=9.24, \mathrm{p}=.0024$ respectively), a finding that suggests an increased pathogen load following contact.

A total of 11 out of 57 individuals (19.3\%) in the pre-contact sample exhibited evidence of infracranial infection. Most of the lesions were non-specific in nature, and involved primarily one or more of the six major long bones. Seven of the affected individuals had active lesions at the time of their death. Twenty-one out of 94 individuals $(22.34 \%)$ in the later sample had infracranial infection involving the six major long bones, as well as ribs, scapulae, clavicles, pelvic bones, and foot bones. Twelve of these individuals had active lesions at the time of death. A statistical comparison of the earlier and later samples revealed no significant difference with respect to the frequency of infracranial infection by individual or by total number of elements (Table 3). Similarly, when cranial and infracranial infection were combined in order to assess the overall prevalence of infection in the study samples, there were no significant differences between the two samples. In contrast, when the pre-contact and Shiprock Island samples were compared separately, the latter sample had a significantly higher frequency of infection, by individual, than the earlier sample (26/62 compared to $11 / 65$ individuals, $\chi^{2}=8.44, p=.0037$ ).

The frequency of dental pathology by individual is presented in Figure 4. Antemortem tooth loss was the most common dental disease observed in both samples, affecting 74\% (42/57 individuals) of the earlier sample and $36 \%(51 / 142$ individuals) of the later sample. In contrast, no caries were observed in either sample. A statistical comparison of the earlier and later samples revealed that significantly more individuals in the earlier sample had abscesses $\left(\chi^{2}=6.75, p=.0094\right)$, antemortem tooth loss $\left(\chi^{2}=21.81, \mathrm{p}<0.00001\right)$, and periodontal disease $\left(\chi^{2}=9.43, \mathrm{p}=.0021\right)$ than in the later sample.

The frequency of dental disease by tooth count is illustrated in Figure 5. Antemortem tooth loss was again the most common form of dental pathology in both samples, affecting 18\% 

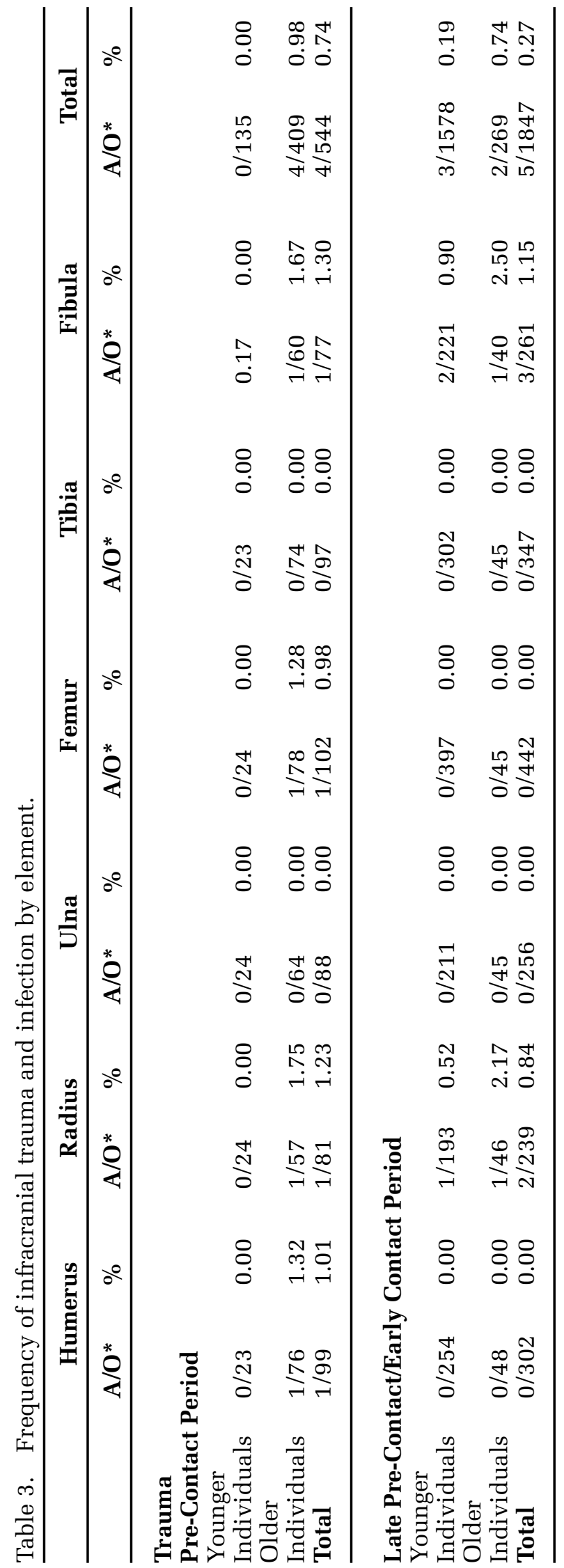

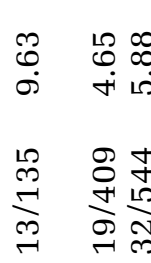

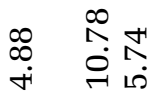

命

곳

\begin{tabular}{lll}
$\Re$ & $m$ & 0 \\
\hdashline & $\oplus$ & 0 \\
0 & $m$ & $\sim$
\end{tabular}

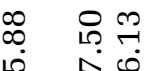

$\stackrel{\overbrace{}}{\curvearrowright} \frac{0}{\circ}$

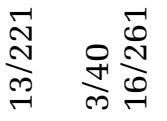

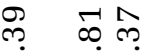

$\stackrel{\sim}{\sim} \stackrel{i}{\mathfrak{1}}$

ช้ เด เด

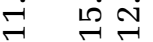

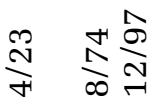

帝造尔

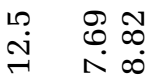

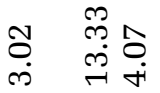

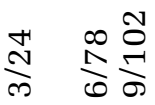

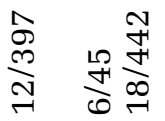

๓ి ㅇำ

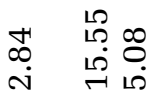

$\infty \dot{0}$ i

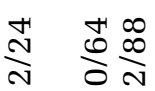

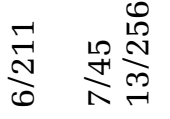

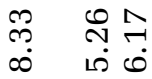

هึ

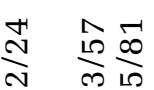

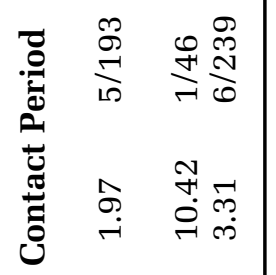

$\begin{array}{lll}尺 & 0 \\ \infty & 0 & 0 \\ \infty & 0\end{array}$

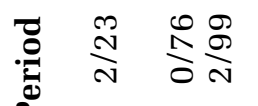

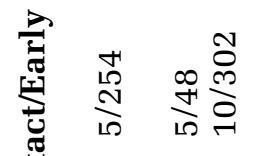

0
0
0
0
0
0

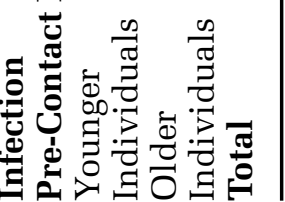

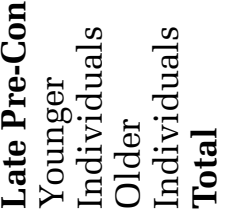




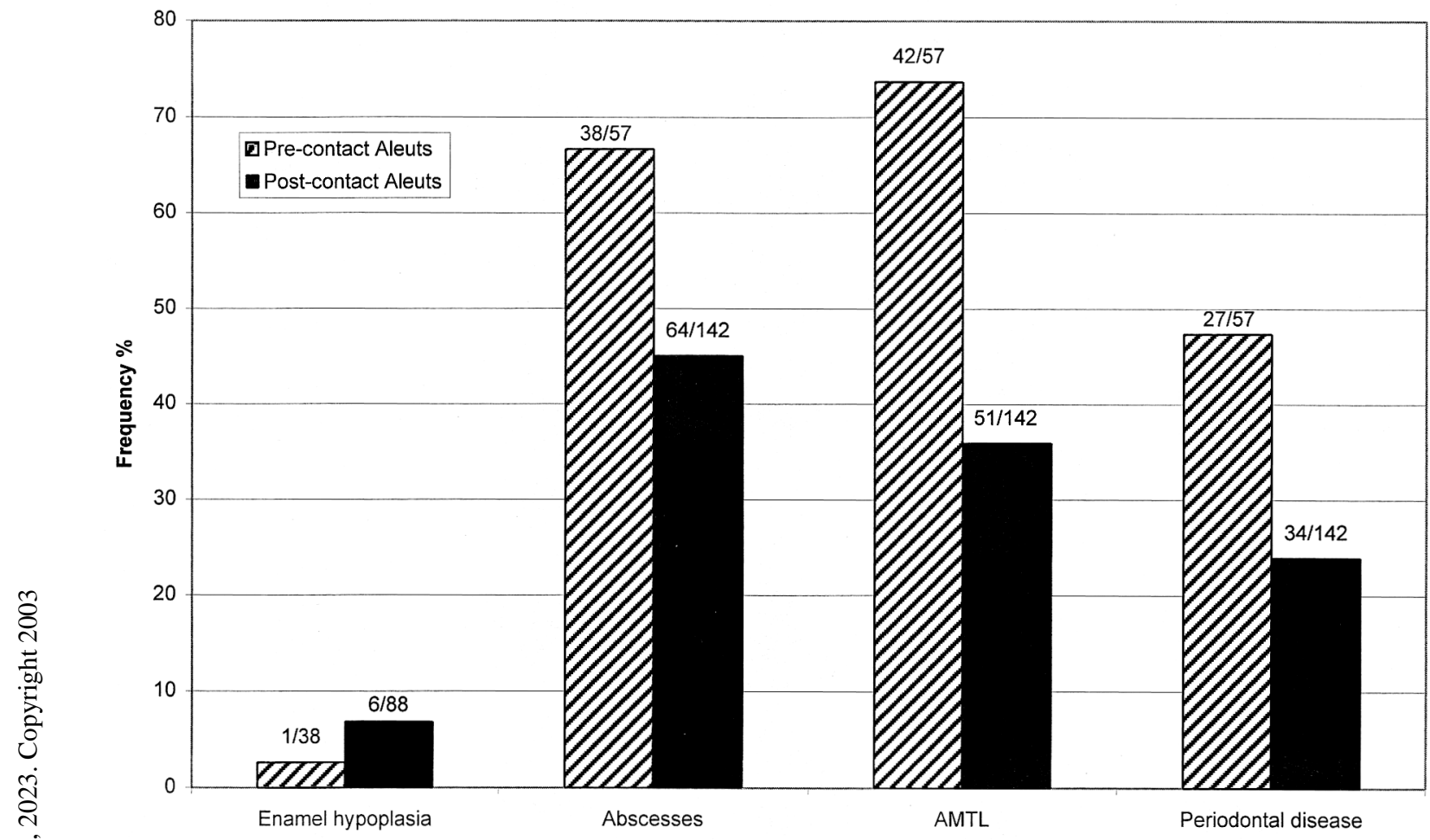

Figure 4. Frequency of dental pathology by individual.

7
0
0
0
0
0
0
0
0
0
0
0
0
0
0
0
0
0

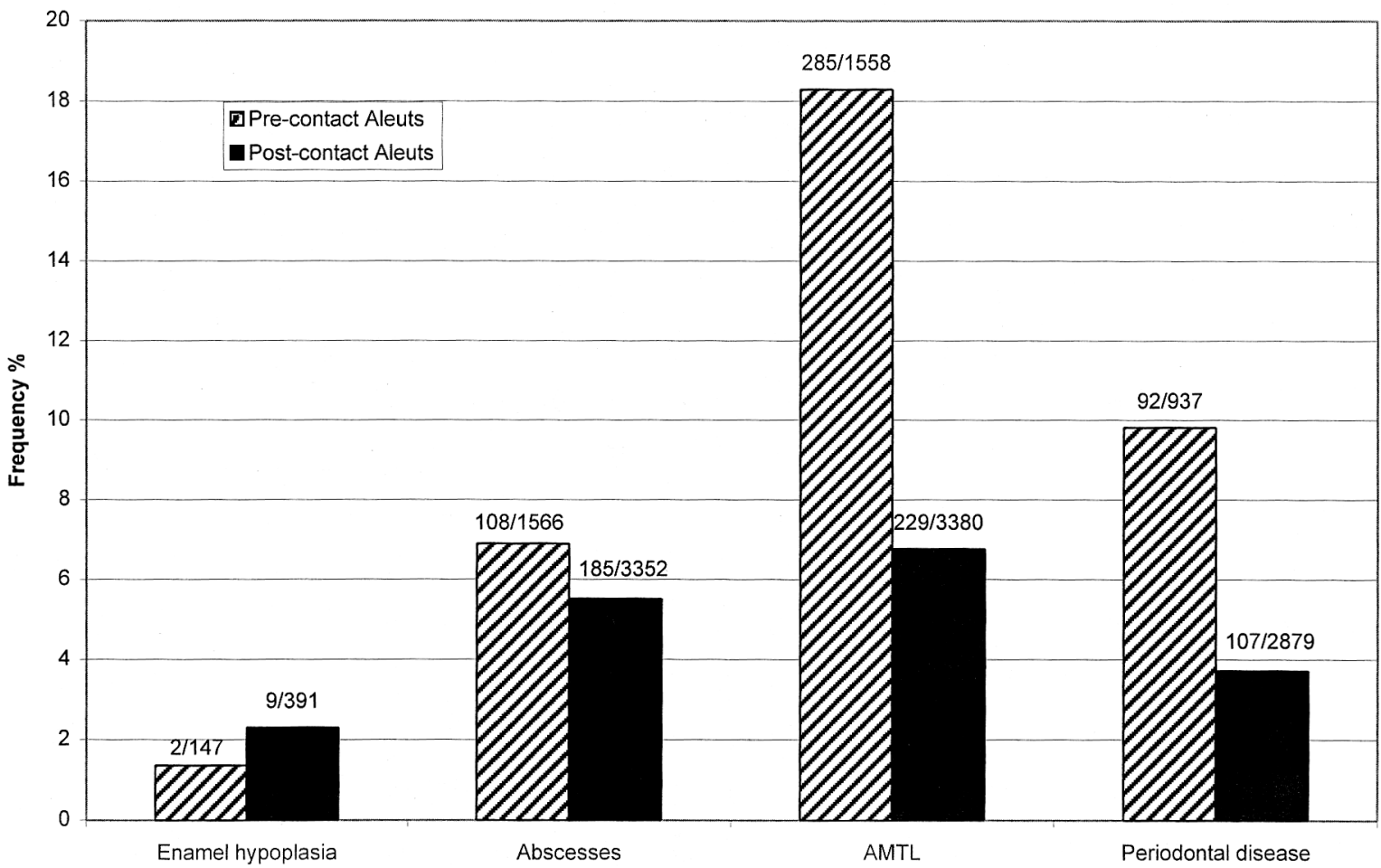

Figure 5. Frequency of dental pathology by tooth. 
(285/1558 teeth) of the earlier sample and $7 \%$ (229/3380 teeth) of the later sample. A statistical comparison of the two samples by sex, age group, tooth type, jaw, and overall tooth count revealed significantly higher frequencies of antemortem tooth loss and periodontal disease in the precontact sample compared to the later sample (Table 4). Possible explanations include high attrition rates and the age distribution of the samples.

\section{Discussion}

Previous research has demonstrated "considerable geographic variability" in the biological impact of contact (Ubelaker and Verano 1992:280). This variability has been attributed, in part, to "differences in the timing and intensity of European contact and colonization" (Verano 1992:21). Fortuine has recognized that historical and biological processes are closely linked, stating that "the very events of history in significant ways determined what the patterns of health and disease would be among the people of Alaska" (Fortuine 1989:87). An examination of historical records reveals a number of factors that may underlie the skeletal evidence of declining health in the later period.

\section{Cribra Orbitalia and Porotic Hyperostosis}

Of particular interest in the present study was the significantly higher frequency of cribra orbitalia in the later sample compared to the earlier one. One possible explanation for this finding is a dietary shift in the early contact period to iron-deficient foods introduced by the Russians. Many of the foods traditionally utilized by the Aleuts, including sea mammal meat, blood soups, bone marrow, liver, waterfowl, and certain species of fish, contain iron in sufficient quantities to prevent anemia (Morehouse 1981). With contact, however, came the introduction of new food items, some of which were iron-deficient. Nevertheless, nutritional changes resulting from contact were reportedly minimal (Milan 1974:21). Rather than replacing traditional food items, Russian foods merely supplemented the aboriginal diet (Milan 1974:21). These foods tended to be given to Creoles (individuals of Russian-Aleut ancestry) rather than Aleuts (Milan 1974:21), and when they were given to the latter, were often insufficient in quality and quantity (Fortuine 1989:116). In fact, only in modern native Alaskan populations has anemia been attributed largely to an inadequate dietary intake of iron (Sauberlich et al. 1972; Scott et al. 1955; Scott and Heller 1964).
The significant increase in cribra orbitalia in the later period may reflect, to some extent, the age distribution of the samples under comparison, specifically, the significantly higher frequency of subadults in the later sample. Seventy-one percent (36/51) of the affected individuals in the later sample were subadults with active lesions. Previous studies have demonstrated higher levels of cribra orbitalia and porotic hyperostosis in subadults, particularly young children, than in adults (Cybulski 1977; Nathan and Haas 1966; Walker 1986). This observation has been attributed to their higher demand for iron during their rapid growth and development (Cybulski 1977; El-Najjar 1976).

If iron deficiency anemia does indeed represent a positive adaptation to a high pathogen load, as Stuart-Macadam (1992) has argued, a more likely explanation for the significantly higher rates of cribra orbitalia in the later period are increased parasitic, bacterial, and viral infections associated with changes in living conditions and the introduction by Europeans of new diseases. In contrast to the moderately-sized houses occupied by the Umnak Island Aleuts prior to contact (Denniston 1966; Turner et al. 1974), during the early contact period the eastern Aleuts occupied large, semisubterranean dwellings that were used for much of the year. They are reported to have contained anywhere from 30 or 40 to several hundred individuals at one time (Makarova 1975; Masterson and Brower 1948). Such crowded living conditions may have facilitated the spread of infections among their occupants (Fortuine 1989). Saunders and colleagues (Saunders et al. 1992) have argued that the longhouses utilized by the Ontario Iroquoians prior to contact may have predisposed them to infections, while in Sarawak, higher incidences of leprosy and tuberculosis have been documented in individuals living in longhouses than in those living in single family houses (Chen 1988).

Compounding the increased opportunity for infection created by the crowded living conditions characteristic of post-contact houses was the lack of sanitation within and around these houses. Numerous historical accounts attest to the lack of both personal and community hygiene in the early contact period. Both Cook ([1776-1780] 1967,3:1) and Sarychev (1807) commented on the fact that garbage and human waste were deposited in the middle of these dwellings. This refuse, combined with the lack of ventilation and uncomfortably high temperatures within these houses undoubtedly provided the opportunity for potentially harmful viruses and bacteria to thrive. A reliance on water 


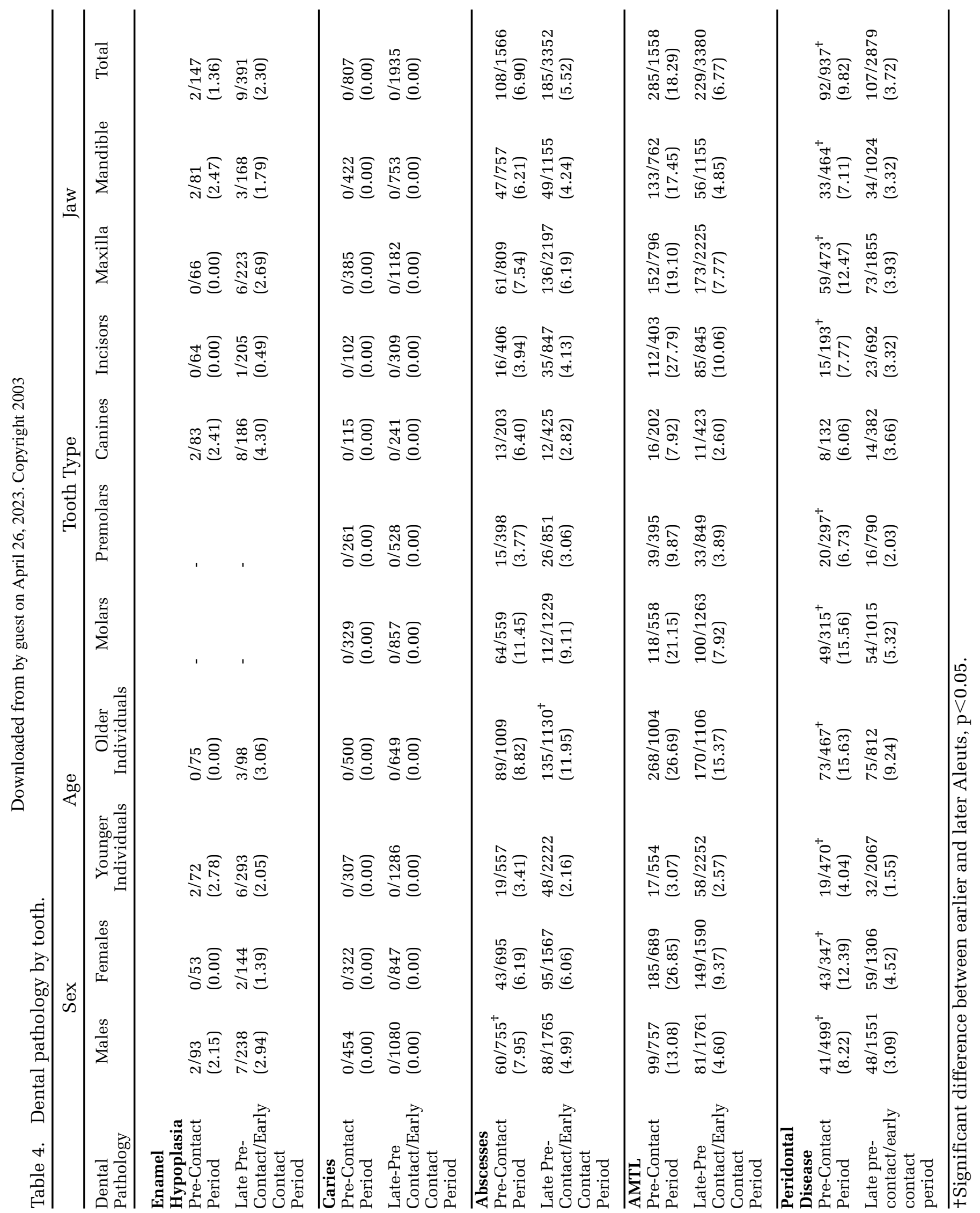


supplies that may have been contaminated (Fortuine 1989) also undoubtedly placed this group at an increased risk of gastrointestinal infections resulting in diarrhea and the subsequent loss of iron. In the early nineteenth century, diarrhea is reported to have been common among the Aleuts, who traditionally used a root extract as a remedy for this condition (Veniaminov [1840] 1984).

The pathogen load affecting the Aleuts during the early contact period would have been further increased by the introduction of new diseases by Europeans. Historical records document the occurrence of numerous epidemics among the Aleuts following contact (Table 5). While evaluating the magnitude of the impact of acute epidemic diseases from skeletal remains is hindered by the fact that these diseases leave no evidence in bone (Ortner 1992:5), an examination of the reported mortality rates resulting from these epidemics clearly illustrates the negative impact of introduced pathogens on this population.

\section{Trauma}

A statistical comparison of the earlier and later samples revealed no significant differences in cranial or infracranial trauma. However, when cranial and infracranial trauma were combined in order to assess the overall prevalence of trauma in the samples, the earlier sample showed significantly more trauma than the later sample. Fractures increase with age, reflecting increased years at risk (Lovejoy and Heiple 1981). Therefore, the significantly higher frequency of trauma in the earlier sample is likely to reflect the significantly higher number of older individuals $(50+$ years) in this sample.

When only younger individuals were compared, there was no significant difference between the two samples.

It was originally hypothesized that a statistical comparison of the earlier and later samples would reveal a significant decline in trauma in the later period. This was based on the observations of Father Ivan Veniaminov, who served as an Orthodox missionary in the eastern Aleutian Islands in the early 19th century. According to native accounts gathered by Veniaminov, warfare between neighboring Aleut settlements and between Aleuts and mainland Eskimos was a frequent occurrence prior to contact, resulting in the destruction of entire settlements and a significant population reduction long before contact (Veniaminov [1840] 1984). The arrival of the Russians, however, reportedly put an end to native warfare (Veniaminov [1840] 1984:185, 250). At the time of his visit to the Aleutian Islands in 1778, Cook commented

Table 5. Epidemics in the Aleutian Islands, 1791-1863.

\begin{tabular}{|c|c|c|c|c|}
\hline Date & Location & Disease & Mortality & Source \\
\hline 1791-92 & Unalaska Is. & "chest diseases" & high & Merck 1980:177 \\
\hline 1802 & Atka Island & “contagious fever” & high & Davydov 1977:105 \\
\hline $1806-7$ & eastern islands & $\begin{array}{l}\text { "high fever and chest } \\
\text { congestion" }\end{array}$ & $>350$ & Black 1984:97 \\
\hline $1807-8$ & western islands & $\begin{array}{l}\text { "high fever and chest } \\
\text { congestion" }\end{array}$ & high & $\begin{array}{l}\text { Vasiliev 1823, cited } \\
\text { in Black 1981:141; } \\
\text { Black 1984:97-98 }\end{array}$ \\
\hline $1807-8$ & eastern islands & dysentery & high & $\begin{array}{l}\text { Veniaminov } \\
1984: 257\end{array}$ \\
\hline 1830-31 & eastern islands & $\begin{array}{l}\text { "cough and chest } \\
\text { congestions" }\end{array}$ & $>30$ & $\begin{array}{l}\text { Veniaminov } \\
\text { 1984:258 }\end{array}$ \\
\hline 1831-32 & $\begin{array}{l}\text { Amlia Is., Atka } \\
\text { Is., Near Is. }\end{array}$ & "coughing sickness" & high & $\begin{array}{l}\text { Netsvetov 1980:55, } \\
74\end{array}$ \\
\hline $1831-32$ & western islands & intestinal infection & high & $\begin{array}{l}\text { Netsvetov, cited in } \\
\text { Black 1981:141 }\end{array}$ \\
\hline 1838 & eastern islands & smallpox & $\sim 85$ & $\begin{array}{l}\text { Veniaminov } \\
1984: 245\end{array}$ \\
\hline 1848 & eastern islands & measles & $\sim 300$ & $\begin{array}{l}\text { Tikhmenev } \\
\text { 1978:371-2; Bancroft } \\
\text { 1959:580 }\end{array}$ \\
\hline 1863 & $\begin{array}{l}\text { Atka and Amlia } \\
\text { Islands }\end{array}$ & influenza & 55 & Black 1984:105 \\
\hline
\end{tabular}


that the Aleuts had been disarmed by the Russians and lived peacefully with one another (Cook [1776-1780] 1967, 3:1:459, 462, 468). Similarly, Sarychev (1807:78) reported peaceful relations among the Unalaskan Aleuts 13 years later. If other accounts are accurate, however, native warfare continued to occur during the contact period (Black 1984:56, 81; Laughlin 1980:54), and in fact may have intensified following contact due to competition for Russian trade (Black 1984:81). The skeletal evidence fails to shed any light on this question.

\section{Infections}

Most noteworthy in this study is the significantly higher frequency of cranial infection in the later ठํ sample compared to the pre-contact sample. As noted earlier, the significant increase in cribra orbitalia in the later sample suggests that infectious ôdiseases increased in the late pre-contact/early . contact period. Possible factors contributing to this کุ่ increase include the transition to larger, more $\overbrace{}^{-c r o w d e d}$ housing and the introduction of new pathogens by Europeans. Of the infectious diseases that affect the cranium, venereal syphilis is the probable cause of the lesions observed in nine $\overrightarrow{\mathrm{s}}$ individuals in the later sample. All nine crania exड્ohibited multiple lytic/proliferative lesions characsteristic of the disease on the outer table of the Ef frontal and/or parietal bones. Holcomb (1940:183) and Steinbock (1976:133) have previously described the remains of two of these individuals as : having lesions indicative of venereal syphilis. Holcomb (1940) also describes five other cases of probable syphilis in post-contact crania from the Aleutian Islands.

At the time of his visit to Unalaska in 1778, Cook noted the presence of venereal diseases among the Aleuts (Cook [1776-1780] 1967, $3: 1: 468)$, and remarked that while the Russians claimed to have no sexual relations with the Aleut women, the English often did. Ship's surgeon David Samwell commented that several of the crewmen contracted venereal disease from Aleut women (Samwell quoted in Cook [1776-1780] 1967,3:2:1144). Another crewman, Captain Charles Clerke, also noted the existence of venereal disease among the Aleuts, and remarked that the Russians had been spreading it among the Kamchadals for many years (Clerke quoted in Cook [1776-1780] 1967,3:2:1337). Venereal disease was reportedly the main health problem of Cook's crew during their third voyage, lasting from
1776 to 1780 . Eight crewmen were afflicted with venereal disease, probably gonorrhoea (Watt 1979:149-150). During his visit to Unalaska in 1791, Merck ([1788-1792] 1980:176) remarked that "wounds of the venereal kind . . . have been known to them [the Aleuts] only since the arrival of Russians." Veniaminov ([1840] 1984:185, 257) cited venereal disease, which he termed "the gift of the Russians", as one of the causes of population decline among the Aleuts after 1790. According to his account, venereal disease appeared in the Aleutians following the arrival of Russians and reached its peak around 1798, when entire families were reportedly infected (Veniaminov [1840] 1984:258). Cited as a major cause of infertility among Aleut women (Veniaminov [1840] 1984:247), with only one out of 11 women of reproductive age giving birth (Veniaminov [1840] 1984:185,257), venereal disease had almost completely disappeared by 1825, usually appearing only in the main settlements (Veniaminov [1840] 1984:258). From 1822 to 1836, 11 Unalaska Aleuts are reported to have died of syphilis (Veniaminov [1840] 1984:488).

Other specific infections known to have been introduced to the Aleuts following contact include tuberculosis. The earliest reference to the presence of this disease among the Aleuts comes from the report of the Russian trader Afanasii Ocheredin, who spent approximately five years in the Aleutian Islands. Two Aleuts, whom he took with him to Siberia in 1770, died of the disease (Bancroft 1959:154n), which they may have contracted from the Russians (Fortuine 1989:256). During Cook's expedition to the Aleutian Islands, two crewmen died of tuberculosis (Cook [1776-1780] 1967, 3:1:699-700; Samwell in Cook 3:2:1130; Watt 1979:149). Either or both of the men who died may have transmitted the disease to the native population prior to their deaths (Fortuine 1989:256). In 1791, an outbreak among the Unalaska Aleuts of a respiratory disease characterized by "pain in the side, coughing and spitting of blood" (Merck [1788-1792] 1980:177) may have been tuberculosis (Fortuine 1989:257). In the western Aleutians, Netsvetov ([1828-1844] 1980:145, 183) reported the deaths of two Aleut women from "consumption" between 1829 and 1842, while in the eastern islands, Veniaminov ([1840] 1984:488) recorded 55 deaths from "phthisis" (pulmonary tuberculosis) during the period from 1822 to 1836.

One adult male in the Shiprock Island sample exhibited active periostitis on the pleural surfaces of the third to eleventh right ribs. While rib 
periostitis is not pathognomonic of pulmonary tuberculosis, and may result from other nontuberculous lung diseases such as pneumonia (Kelley and Micozzi 1984; Pfeiffer 1991; Wakely et al. 1991), tuberculosis cannot be ruled out. Given that individuals with malnutrition and other infectious diseases are most susceptible to tuberculosis (Powell 1992:43), the disease may well have been a serious health threat to the Aleuts during the early contact period, particularly in view of the significantly higher frequencies of cribra orbitalia and cranial infection in the later sample.

\section{Dental Pathology}

A statistical comparison of the earlier and later samples revealed no evidence of declining dental health over time. This finding is consistent with reports of native dental health by early visitors to Alaska. Veniaminov ([1840] 1984:162), for example, noted that the Aleuts had sound, white, heavily worn teeth that became stained yellow or black in older individuals. The absence of caries in the later sample is also consistent with what is known from historical accounts about dietary changes resulting from contact. As noted earlier, dietary changes among the Aleuts are reported to have been minimal in the early contact period (Milan 1974:21). Ships sailing to the Aleutians usually carried only a small supply of foods such as butter, flour, ham, and dried and salted fish (Bancroft 1959:235), relying instead on hunting and fishing for most of their diet. While the Russians supplied the Aleuts with food on occasion, most notably during times of famine, in order to secure furs (Bancroft 1959:237, 580-581), these foods supplemented rather than replaced the traditional native diet and, as noted earlier, were given primarily to Creoles rather than Aleuts (Milan 1974:21). Low rates of caries have also been linked to heavy attrition or tooth wear, which removes areas susceptible to caries, such as pits and fissures (Maat and Van der Velde 1987). Since both Aleut samples exhibited high rates of dental wear (Table 6), this is likely to have contributed to the low rate of caries seen in these samples.

Statistical comparisons of the two samples revealed significantly higher frequencies of abscesses, antemortem tooth loss, and periodontal disease by individual and by tooth count in the pre-contact sample compared to the later sample. These differences most likely reflect the significantly higher number of older adults (50+ years) in the earlier sample. When only younger individ- uals were compared, there were no significant differences between the two samples with the exception of a significantly higher frequency of periodontal disease by tooth in the earlier sample $\left(\chi^{2}=10.86, p=.0010\right)$.

The high rate of attrition in the Aleut samples likely contributed to the loss of teeth in these individuals. Abscesses and periodontal disease, although less common, may also have contributed to the loss of teeth in these groups, particularly the molar teeth which were most frequently affected by these conditions. Attrition was also likely an important factor in the development of abscesses and periodontal disease among the Aleuts.

\section{Conclusions}

The problems of making inferences about the health of past populations from skeletal remains are well recognized. Limitations of paleopathological data include the fact that 1) many diseases, particularly acute infectious diseases, leave no evidence in bone; 2) different diseases may produce similar skeletal changes, making an accurate diagnosis difficult; and 3) skeletal samples are not always representative of the populations from which they are derived, hindering the determination of "population prevalences of pathological conditions from skeletal lesion frequencies" (Wood et al. 1992:345). Nevertheless, paleopathological data can provide some insight into patterns of health and disease in past populations, particularly when multiple indicators of stress are employed (Goodman 1993; Wright and Yoder 2003), and when the data are used in conjunction with other sources of information on health, such as archaeological, historical, and epidemiological data (Goodman 1993; Herring 1992; Larsen 1994).

The data obtained in the present study indicate some evidence of declining health among the Aleuts over time, as indicated by the significantly higher frequencies of cribra orbitalia and cranial infection in the late pre-contact/early contact period sample compared to the pre-contact sample. Some of this decline appears to be related to European contact, more specifically the introduction of new pathogens. Given that their health was already compromised prior to contact (Keenleyside 1998), the Aleuts may have been even more susceptible to these pathogens.

While disease has often been viewed as the primary cause of population decline among Native Americans following contact, other contributing factors included the exploitation of local people 


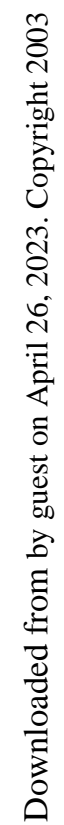

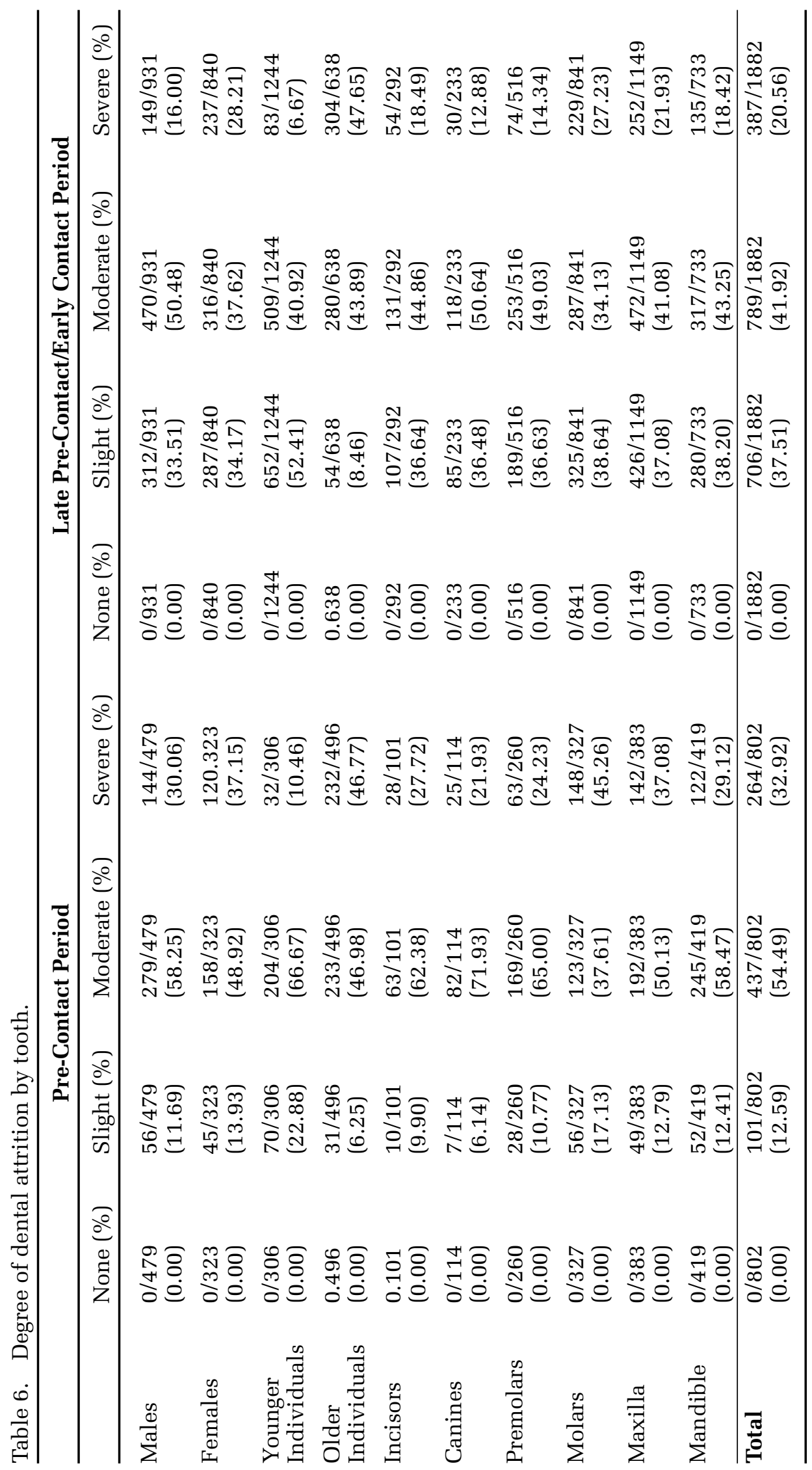


for labor, dietary changes resulting in nutritional stress, hostilities between Europeans and indigenous populations, and social disruption (Larsen 2000:166). Among the Aleuts, hostile encounters with Russians and the practice of forced labor compounded the decline that resulted from the introduction of infectious diseases.

Acknowledgements. I thank Shelley Saunders for her support, advice, and encouragement throughout this research. Thanks also go to David Damas, Peter Ramsden, and Ann Herring of the Department of Anthropology, McMaster University, and to Charles Merbs for their invaluable assistance in the preparation of the doctoral dissertation from which this paper is derived. I am grateful to the following individuals in the Department of Anthropology, National Museum of Natural History, Smithsonian Institution: David Hunt and Carol Butler for allowing me access to the skeletal material, Doug Owsley, Bob Mann, and Don Ortner for their guidance and advice throughout this research, and Fran Albrecht for radiographing some of the pathological specimens. This research was supported by the Social Sciences and Humanities Research Council of Canada (Doctoral Fellowship), an Ontario Graduate Scholarship, McMaster University School of Graduate Studies, a Smithsonian Graduate Fellowship, and a Sigma Xi Grant-in-Aid of Research.

\section{References Cited}

Aufderheide, Arthur C.

1992 Summary on Disease Before and After Contact. In Disease and Demography in the Americas.

J. W. Verano and D. H. Ubelaker, eds. Pp. 165-166. Washington, D.C.: Smithsonian Institution Press.

Baker, Brenda J. and L. Kealhofer (eds.)

1996 Bioarchaeology of Native American Adaptation in the Spanish Borderlands. Gainesville: University Press of Florida.

Bancroft, Hubert $\mathrm{H}$.

1959 History of Alaska 1730-1885. New York: Antiquarian Press.

Bass, William M.

1987 Human Osteology: A Laboratory and Field Manual of the Human Skeleton, 3rd Ed. Special Publication no. 2, Columbia: Missouri Archeological Society.

Beckett, S. and Nancy C. Lovell

1994 Dental Disease Evidence for Agricultural Intensification in the Nubian C-Group. International Journal of Osteoarchaeology 4:223-240.

Berkh, Vasilii N.

[1823] Chronological History of the Discovery of the

1974 Aleutian Islands or the Exploits of Russian
Merchants [1823]. Richard A. Pierce, ed. Kingston: The Limestone Press.

Black, Lydia T.

1980 Early History. In The Aleutians. Theme Issue. Alaska Geographic 7(3):82-105.

1981 The Nature of Evil: Of Whales and Sea Otters. In Indians, Animals, and the Fur Trade.

Shepard Krech, III, ed. Pp. 109-153. Athens: University of Georgia Press.

1983 Some Problems in Interpretation of Aleut Prehistory. Arctic Anthropology 20(1):49-78.

1984 Atka: An Ethnohistory of the Western Aleutians. Kingston: The Limestone Press.

Chen, Paul C. Y.

1988 Longhouse Dwelling, Social Contact, and the Prevalence of Leprosy and Tuberculosis among Native Tribes of Sarawak. Social Science and Medicine 26(10):1073-1077.

Cohen, Mark N. and George J. Armelagos

1984 Paleopathology at the Origins of Agriculture. Toronto: Academic Press.

Cook, James

[1776- The Journals of Captain James Cook on his

1780] Voyages of Discovery, Volume 3. J. C.

1967 Beaglehole, ed. The Voyage of the Resolution and Discovery 1776-1780 (in two parts). Cambridge: Hakluyt Society.

Costa, Raymond L. Jr.

1980 Sex and Antemortem Loss of Teeth in Prehistoric Eskimo Samples from Point Hope and Kodiak Island, Alaska. American Journal of Physical Anthropology 53(4):579-587.

1982 Periodontal Disease in the Prehistoric Ipiutak and Tigara Skeletal Remains from Point Hope, Alaska. American Journal of Physical Anthropology 59(1):97-110.

Coxe, William

1780 Account of the Russian Discoveries between Asia and America. London: J. Nichols.

Cybulski, Jerome S.

1977 Cribra Orbitalia, A Possible Sign of Anemia in Early Historic Native Populations of the British Columbia Coast. American Journal of Physical Anthropology 47(1):31-40.

Dall, William H.

1875 Alaskan Mummies. American Naturalist 9(8):433-440.

Davydov, Gavrila I.

[1802- Two Voyages to Russian America, 1802-1807.

1807] Richard A. Pierce, ed. Kingston: The

1977 Limestone Press.

Denniston, Glenda B.

1966 Cultural Change at Chaluka, Umnak Island: Stone Artifacts and Features. Arctic Anthropology 3(2):84-124. 
El-Najjar, M. Y.

1976 Maize, Malaria, and the Anemias in the PreColumbian New World. Yearbook of Physical Anthropology 20:329-337.

El-Najjar, M. Y., D. J. Ryan, C. G. Turner, and B. Lozoff 1976 The Etiology of Porotic Hyperostosis among the Prehistoric and Historic Anasazi Indians of Southwestern United States. American Journal of Physical Anthropology 44(3):477-488.

Federation Dentaire International

1982 An Epidemiologic Index of Developmental Defects of Dental Enamel (DDE Index). International Dental Journal 32:159-167.

Fedorova, Svetlana G.

1973 The Russian Population in Alaska and California. Kingston: The Limestone Press.

Fortuine, Robert

1989 Chills and Fever: Health and Disease in the Early History of Alaska. Fairbanks: University of Alaska Press.

Glushankov, I. V.

1973 The Aleutian Expedition of Krenitsyn and Levashov. M. Sadouski and R. A. Pierce, trans. Alaska Journal 3(3):204-210.

ㄱ. Goodman, Alan H.

1993 On the Interpretation of Health from Skeletal Remains. Current Anthropology 34(3):281-288.

范 Goodman, Alan H. and George J. Armelagos.

क्. 1985 Factors Affecting the Distribution of Enamel Hypoplasias within the Human Permanent Dentition. American Journal of Physical Anthropology 68(4):479-493.

Goodman, Alan H., Debra L. Martin, George J. Armelagos, and G. Clark

1984 Indications of Stress from Bone and Teeth. In Paleopathology at the Origins of Agriculture. Mark N. Cohen and George J. Armelagos, eds. Pp. 13-49. Toronto: Academic Press.

Heathcote, Gary M.

1986 Exploratory Human Craniometry of Recent Eskaleutian Regional Groups from the Western Arctic and Subarctic of North America. Oxford: BAR International Series no. 301.

Herring, D. Ann

1992 Toward a Reconsideration of Disease and Contact in the Americas. Prairie Forum. 17(2):153-165.

Holcomb, Richmond C.

1940 Syphilis of the Skull among Aleuts, and the Asian and North American Eskimo about Bering and Arctic Seas. U.S. Naval Medical Bulletin 38:177-192.

Hrdlička, Ales

1941a Exploration of Mummy Caves in the Aleutian Islands. Part 1. Previous Knowledge of Such
Caves. Original Explorations. Scientific

Monthly 52(1):5-23.

1941b Exploration of Mummy Caves in the Aleutian Islands. Part 2. Further Exploration. Scientific Monthly 52(2):113-130.

1945 The Aleutian and Commander Islands and Their Inhabitants. Philadelphia: Wistar Institute of Anatomy and Biology.

Hulley, Clarence C.

1953 Alaska 1741-1953. Portland: Binfords and Mort.

Iscan, M. Y., S. R. Loth, and R. K. Wright

1984 Age Estimation from the Ribs by Phase Analysis: White Males. Journal of Forensic Science 29:1094-1104.

1985 Age Estimation from the Ribs by Phase Analysis: White Females. Journal of Forensic Science 30:853-863.

Jochelson, Waldemar

1925 Archaeological Investigations in the Aleutian Islands. Washington, D.C.: Carnegie Institution of Washington Publication no. 367.

1968 History, Ethnology, and Anthropology of the Aleut. The Netherlands: Anthropological Publications.

Keenleyside, Anne

1998 Skeletal Evidence of Health and Disease in PreContact Alaskan Eskimos and Aleuts. American Journal of Physical Anthropology 107 (1):51-70.

Kelley, Marc A. and Mark S. Micozzi

1984 Rib Lesions in Chronic Pulmonary Tuberculosis. American Journal of Physical Anthropology 65(4):381-386.

Lantis, Margaret

1984 Aleut. In Handbook of North American Indians, volume 5, Arctic. David Damas, ed. Pp. 161-184. Washington, D.C.: Smithsonian Institution Press.

Larsen, Clark Spencer

1994 In the Wake of Columbus: Native Population Biology in the Postcontact Americas. Yearbook of Physical Anthropology 37:109-154.

1997 Bioarchaeology. Interpreting Behaviour from the Human Skeleton. Cambridge: Cambridge University Press.

2000 Skeletons in Our Closet: Revealing Our Past through Bioarchaeology. Princeton, New Jersey: Princeton University Press.

2001 Bioarchaeology of Spanish Florida: The Impact of Colonialism. Gainesville: University Press of Florida.

Larsen, Clark S. and G. R. Milner (eds.)

1994 In the Wake of Contact: Biological Responses to Conquest. New York: Wiley-Liss. 
Laughlin, William S.

1963 Eskimos and Aleuts: Their Origins and Evolution. Science 142(3593):633-45.

1980 Aleuts: Survivors of the Bering Land Bridge. Toronto: Holt, Rinehart, and Winston.

1992 Geographic and Temporal Variation in Aleuts (Unangan) and Prehistory. Grant proposal in the author's possession.

Laughlin, William S. and Jean S. Aigner

1975 Aleut Adaptation and Evolution. In Prehistoric Maritime Adaptations of the Circumpolar Zone. William Fitzhugh, ed. Pp. 181-201. Paris: Mouton.

Liapunova, R. G.

1987 Relations with the Natives of Russian America. In Russia’s American Colony. S. F. Starr, ed. Pp. 105-143. Durham, N.C.: Duke University Press.

Lippold, Lois K.

1966 Chaluka: The Economic Base. Arctic Anthropology 3(2):125-131.

Lobdell, John E.

1980 Prehistoric Human Population Resource Utilization in Kachemak Bay, Gulf of Alaska. Ph.D. dissertation, Dept. of Anthropology, University of Tennessee.

Lovejoy, C. Owen and K. G. Heiple

1981 The Analysis of Fractures in Skeletal Populations with an Example from the Libben Site, Ottowa County, Ohio. American Journal of Physical Anthropology 55(4):529-541.

Lovell, Nancy C.

1997 Trauma Analysis in Paleopathology. Yearbook of Physical Anthropology 40:139-170.

Maat, G. J. R. and E. A. Van der Velde

1987 The Caries-Attrition Competition. International Journal of Anthropology 2(4):281-292.

Makarova, Raisa V.

1975 Russians on the Pacific 1743-1799. R. A. Pierce and A. Donnelly, eds. Kingston: The Limestone Press.

Mann, Robert W. and Sean P. Murphy

1990 Regional Atlas of Bone Disease. Springfield, Illinois: Charles C. Thomas.

Mann, Robert W., Richard L. Jantz, William M. Bass, and P. Willey

1991 Maxillary Suture Obliteration: A Visual Method for Estimating Skeletal Age. Journal of Forensic Science 36(3):781-791.

Masterson, James R. and Helen Brower

1948 Bering's Successors 1745-1780. Contributions of Peter Simon Pallas to the History of Russian Exploration toward Alaska. Seattle: University of Washington Press.
Mayhall, John T.

1970 The Effect of Culture Change upon the Eskimo Dentition. Arctic Anthropology 7(1):117-121.

1975 Canadian Inuit Caries Experience. Journal of Dental Research 54(6):1245.

McCartney, Allen P.

1984 Prehistory of the Aleutian Region. In Handbook of North American Indians, volume 5, Arctic. David Damas, ed. Pp. 119-135. Washington, D.C.: Smithsonian Institution Press.

Meer, Rosie M.

1985 Health and Disease in Protohistoric Alaska. Paper presented at the Eighty-fourth Annual Meeting of the American Anthropological Association, Washington D.C.

Mensforth, R. C., C. Owen Lovejoy, J. Lallo, and George J. Armelagos

1978 The Role of Constitutional Factors, Diet, and Infectious Disease in the Etiology of Porotic Hyperostosis and Periosteal Reactions in Prehistoric Infants and Children. Medical Anthropology 2:1-59.

Merbs, Charles F.

1968 Anterior Tooth Loss in Arctic Populations. Southwestern Journal of Anthropology $24: 20-32$.

1983 Patterns of Activity-Induced Pathology in a Canadian Inuit Population. National Museum of Man Mercury Series, Archaeological Survey of Canada Paper, no.119, Ottawa.

Merck, Carl Heinrich

[1788- Siberia and Northwestern America 1788-1792.

1792] The Journal of Carl Heinrich Merck, Naturalist

1980 with the Russian Scientific Expedition Led by Captains Joseph Billings and Gavril Sarychev. Richard A. Pierce, ed. Kingston: The Limestone Press.

Milan, Leda Chase

1974 Ethnohistory of Disease and Medical Care among the Aleut. Anthropological Papers of the University of Alaska 16(2):15-40.

Morehouse, Karen B.

1981 Alaskan Native Diet and Nutrition: An Ethnohistorical View. Master's thesis, Department of Anthropology, University of Alaska.

Nathan, H. and N. Haas

1966 "Cribra Orbitalia": A Bone Condition of the Orbit of Unknown Nature. Israel Journal of Medical Science 2:171-191.

Netsvetov, Iakov

[1828- The Journals of Iakov Netsvetov: The Atkha

1844] Years, 1828-1844. Lydia T. Black, trans.

1980 Kingston: The Limestone Press. 
Okun, Semen B.

1951 The Russian-American Company. Cambridge: Harvard University Press.

Ortner, Donald J. and Walter G. J. Putschar

1985 Identification of Pathological Conditions in $\mathrm{Hu}-$ man Skeletal Remains. Reprint, Smithsonian Contributions to Anthropology, no. 28. Washington, D.C.: Smithsonian Institution Press.

Ortner, Donald J.

1992 Skeletal Paleopathology: Probabilities, Possibilities, and Impossibilities. In Disease and Demography in the Americas. John W. Verano and Douglas H. Ubelaker, eds. Pp. 5-13. Washington, D.C.: Smithsonian Institution Press.

Patterson, David K. Jr.

1984 A Diachronic Study of Dental Palaeopathology and Attritional Status of Prehistoric Ontario Pre-Iroquois and Iroquois Populations. National Museum of Man Mercury Series, Archaeological Survey of Canada Paper no.122, Ottawa.

Pfeiffer, Susan

1991 Rib Lesions and New World Tuberculosis. International Journal of Osteoarchaeology 1:191-198.

¿ิPowell, Mary Lucas

- 1992 Health and Disease in the Late Prehistoric Southeast. In Disease and Demography in the Americas. John W. Verano and Douglas H. Ubelaker, eds. Pp. 41-53. Washington, D.C.: Smithsonian Institution Press.

Rose, J. C., S. C. Anton, A. C. Aufderheide, J. E. Buikstra, İ L. Eisenberg, J. B. Gregg, E. E. Hunt, E. J. Neiburger, and $\Xi$ B. Rothschild

¿ 1991 Skeletal Database Committee Recommendations. Detroit: Paleopathology Association.

Salter, Elizabeth

1984 The Skeletal Biology of Cumberland Sound, Baffin Island, N.W.T. Ph.D. Dissertation, Department of Anthropology, University of Toronto, Ontario, Canada.

Sarychev, Gavrilo

[1807] The Voyage of Captain Sarychev through

1969 Northeastern Siberia, the Arctic Sea, and the Eastern Ocean, Lasting Eight Years and Undertaken in Connection with the Geographic and Astronomic Naval Expedition under Command of Captain Billings in the Years 1785-1793. St. Petersburg: Schnor.

Sauberlich, H. E., W. Goad, Y. F. Herman, F. Milan, and P. Jamison

1972 Biochemical Assessment of the Nutritional Status of the Eskimos of Wainwright, Alaska. American Journal of Clinical Nutrition 25(1):437-445.
Saunders, Shelley R., Peter G. Ramsden, and D. Ann Herring

1992 Transformation and Disease: Precontact Ontario Iroquoians. In Disease and Demography in the Americas. John W. Verano and Douglas H. Ubelaker, eds. Pp. 117-125. Washington, D.C.: Smithsonian Institution Press.

Schultz, Michael

2001 Paleohistopathology of Bone: A New Approach to the Study of Ancient Diseases. Yearbook of Physical Anthropology 44:106-147.

Scott, E. M., R. C. Wright, and B. T. Hanan

1955 Anemia in Alaskan Eskimos. Journal of Nutrition 55:137-149.

Scott, E. M. and C. A. Heller

1964 Iron Deficiency in Alaskan Eskimos. American Journal of Clinical Nutrition 15:282-286.

Smith, B. Holly

1984 Patterns of Molar Wear in Hunter-Gatherers and Agriculturalists. American Journal of Physical Anthropology 63(1):39-56.

Steinbock, R. Ted

1976 Paleopathological Diagnosis and Interpretation. Springfield, Illinois: Charles C. Thomas.

Stewart, T. Dale

1932 The Vertebral Column of the Eskimo. American Journal of Physical Anthropology 17(1):123-136.

1979 Patterning of Skeletal Pathologies and Epidemiology. In The First Americans: Origins, Affinities, and Adaptations. William S. Laughlin and A. B. Harper, eds. Pp. 257-274. New York: Gustav Fischer.

Stuart-Macadam, Patricia

1992 Porotic Hyperostosis: A New Perspective. American Journal of Physical Anthropology 87(1):39-47.

Suchey, Judy M. and D. Katz

1986 Skeletal Age Standards Derived from an Extensive Sample of Modern Americans. Paper presented at the Fifty-fifth Annual Meeting of the American Association of Physical Anthropologists, Albuquerque, New Mexico.

Suchey, Judy M., S. T. Brooks, and D. Katz

1988 Instructional Materials Accompanying Female Pubic Symphyseal Models of the Suchey-Brooks System. Distributed by France Casting (1713 Willox Court, Unit A, Fort Collins, Colorado, 80524).

Tikhmenev, Petr Aleksandrovich

1978 A History of the Russian-American Company. R. A. Pierce and A. S. Donnelly, eds. Seattle: University of Washington Press. 
Turner, Christy G. II

1991 The Dentition of Arctic Peoples. New York: Garland Publishing.

Turner, Christy G. II, J. S. Aigner, and L. R. Richards 1974 Chaluka Stratigraphy, Umnak Island, Alaska. Arctic Anthropology 11 (Suppl. vol.):125-142.

Turner, Christy G. II, P. W. Mamula, and C. J. Utermohle 1982 New Anthropological Evidence Bearing on the Issue of Neo-Aleut Origins. Arctic Anthropology 19(1):127-138.

Ubelaker, Douglas H.

1989 Human Skeletal Remains. 2nd Ed. Washington, D.C.: Taraxacum.

Ubelaker, Douglas H. and John W. Verano

1992 Conclusion. In Disease and Demography in the Americas. John W. Verano and Douglas H. Ubelaker, eds. Pp. 279-282. Washington, D.C.: Smithsonian Institution Press.

Utermohle, Charles J.

1984 From Barrow Eastward: Cranial Variation of the Eastern Eskimo. Ph.D. Dissertation, Department of Anthropology, Arizona State University.

VanStone, James W.

1984 Exploration and Contact History of Western Alaska. In Handbook of North American Indians, vol. 5, Arctic. David Damas, ed. Pp. 149-160. Washington, D.C.: Smithsonian Institution Press.

Vasiliev, Ivan

1823 Vypiski iz Puteshestviya Shturmana Vasil'yeva, Ivana Filipovocha na Sudne Finlandia 1811-12 g, v Aleutskikh Ostrovakh (Extracts from the Account of a Voyage by the Navigator Vasil'yev, Ivan F., on the Vessel Finlandia in the Years 1811-12 in the Aleutian Islands). Novosti Literatury 6(49):152-58, 6(50):161-68, 6(51):177-85, 6(52):193-200.

Veniaminov, Ivan

[1840] Notes on the Islands of the Unalaska District.

1984 Richard A. Pierce, ed., Lydia T. Black and R. H. Geoghegan, trans. Kingston: The Limestone Press.

Verano, John W.

1992 Prehistoric Disease and Demography in the Andes. In Disease and Demography in the Americas. John W. Verano and Douglas H. Ubelaker, eds. Pp. 15-24. Washington, D.C.: Smithsonian Institution Press.

Verano, John W. and Douglas H. Ubelaker (eds.) 1992 Disease and Demography in the Americas. Washington, D.C.: Smithsonian Institution Press.
Wakely, Jennifer, Keith Manchester, and Charlotte A. Roberts

1991 Scanning Electron Microscopy of Rib Lesions. International Journal of Osteoarchaeology 1:185-189.

Waldram, James B, D. Ann Herring, and T. Kue Young 1995 Aboriginal Health in Canada: Historical, Cultural, and Epidemiological Perspectives. Toronto: University of Toronto Press.

Walker, Philip L.

1986 Porotic Hyperostosis in a Marine-Dependent California Indian Population. American Journal of Physical Anthropology 69(3):345-354.

Watt, James

1979 Medical Aspects and Consequences of Cook's Voyages. In Captain James Cook and his Times, R. Fisher and H. Johnston, eds. Pp. 129-57. Seattle: University of Washington Press.

Way, J. E.

1978 An Osteological Analysis of a Late Thule/Early Historic Labrador Eskimo Population. Ph.D. Dissertation, Department of Anthropology, University of Toronto, Ontario, Canada.

Wood, J. W., G. R. Milner, H. C. Harpending, and K. M. Weiss

1992 The Osteological Paradox: Problems of Inferring Prehistoric Health from Skeletal Samples. Current Anthropology 33(4):343-370.

Wright, Lori E. and Cassady J. Yoder

2003 Recent Progress in Bioarchaeology: Approaches to the Osteological Paradox. Journal of Archaeological Research 11(1):43-70.

Zimmerman, Michael R. and Arthur C. Aufderheide 1984 The Frozen Family of Utqiagvik: The Autopsy Findings. Arctic Anthropology 21(1):53-64.

Zimmerman, Michael R. and G. S. Smith

1975 A Probable Case of Accidental Inhumation of 1600 Years Ago. Bulletin of the New York Academy of Medicine 51(7):828-837.

Zimmerman, Michael R., G. W. Yeatman, and H. Sprinz 1971 Examination of an Aleutian Mummy. Bulletin of the New York Academy of Medicine 47(1):80-103.

Zimmerman, Michael R., E. Trinkaus, M. LeMay, A. C. Aufderheide, T. A. Reyman, G. R. Marrocco, R. W. Ortel, J. T. Benitez, W. S. Laughlin, P. D. Horne, R. E. Schultes, and E. A. Coughlin

1981 Paleopathology of an Aleutian Mummy. Archives of Pathology and Laboratory Medicine 105:638-641. 